\title{
Uneven temperature and voltage distributions due to rapid discharge rates and different boundary conditions for series-connected $\mathrm{LiFePO}_{4}$ batteries
}

\author{
S. Panchal*1 ${ }^{1}$, I. Dincer ${ }^{1}$, M. Agelin-Chaab ${ }^{1}$, M. Fowler ${ }^{2}$ and R. Fraser $^{3}$ \\ ${ }^{1}$ Department of Automotive, Mechanical \& Manufacturing Engineering, Faculty of Engineering \& \\ Applied Science, University of Ontario Institute of technology, 2000 Simcoe Street North, Oshawa, \\ Ontario, Canada, L1H 7K4 \\ ${ }^{2}$ Chemical Engineering Departments, University of Waterloo, 200 University Avenue West, Waterloo, \\ Ontario, Canada, N2L 3G1 \\ ${ }^{3}$ Mechanical and Mechatronic Engineering Department, University of Waterloo, 200 University Avenue \\ West, Waterloo, Ontario, Canada, N2L 3G1 \\ *Corresponding Author's Email: satyam.panchal@uwaterloo.ca, satyam.panchal@uoit.ca \\ *Corresponding Author's Telephone: +1-519-722-4420
}

\begin{abstract}
This paper presents the surface temperature and voltage distributions on a prismatic lithium-ion battery pack at $1 \mathrm{C}, 2 \mathrm{C}, 3 \mathrm{C}$, and $4 \mathrm{C}$ discharge rates and $5^{\circ} \mathrm{C}, 15^{\circ} \mathrm{C}, 25^{\circ} \mathrm{C}$, and $35^{\circ} \mathrm{C}$ boundary conditions (BCs) for water cooling and $\sim 22^{\circ} \mathrm{C}$ for an air cooling method to provide quantitative data regarding thermal behaviour of lithium-ion batteries for designing thermal management systems and developing reliable thermal models. In this regard, three large, $\mathrm{LiFePO}_{4} 20 \mathrm{Ah}$ capacity, prismatic batteries are connected in series with four cold plates used between cells and eighteen thermocouples are placed at distributed locations on the principle surface of all three cells: the first six for the first cell, the second six for the second cell, and the third six for the third cell, and the average and peak surface temperatures as well as voltage distributions are measured and presented in this study. In addition, using MATLAB Simulink, the simulated heat generation rate, temperature and voltage distributions are validated with an experimental data for the above mentioned C-rates and BCs. The present study shows that increasing discharge rates and BCs results in increase the maximum and average surface temperature at the three locations (first near the anode, the second near the cathode, and the third near the mid surface of the body). The highest value of the average surface temperature is obtained for $4 \mathrm{C}$ and $35^{\circ} \mathrm{C} \mathrm{BC}\left(36.36^{\circ} \mathrm{C}\right)$ and the lowest value is obtained for $1 \mathrm{C}$ and $5^{\circ} \mathrm{C} \mathrm{BC}\left(7.22^{\circ} \mathrm{C}\right)$ for water cooling method.
\end{abstract}

Keywords: Lithium-ion battery cells, temperature distribution, thermal management.

\section{Introduction}

In the automotive sector, powertrain electrification, which consists Electric vehicles (EVs), Hybrid Electric Vehicles (HEVs), and Plug-In Hybrid Electric Vehicles (PHEVs) has recently achieved more attention for reducing the $\mathrm{CO}_{2}$ emissions $[1,2]$. Consensus in the automotive sector is that lithium-ion 
batteries are the most likely candidate for overcoming this challenge [1]. Also, the lithium-ion battery is the most advanced battery technology for EVs, HEVs, and PHEVs due to: 1) high specific energy and power densities [3, 4]; 2) high nominal voltage and low self-discharge rate [5]; and 3) long cycle-life and no memory effect $[6,7]$. A lithium-ion battery cells usually has five different layers, namely: the negative current collector, negative electrode (anode), separator, positive electrode (cathode), and positive current collector. The positive electrode materials [8,9] are typically four types: 1) a metal oxide with layered structure, such as lithium cobalt oxide $\left(\mathrm{LiCoO}_{2} / \mathrm{LCO}\right)$ [10]; 2) a metal with a three dimensional spinal structure, such as lithium manganese oxide $\left(\mathrm{LiMn}_{2} \mathrm{O}_{4}\right)$ [11]; 3) lithium nickel manganese cobalt oxide ( $\left.\mathrm{LiNiMnCoO}_{2} / \mathrm{NMC}\right)$; and 4) a metal with a olivine structure, such as lithium iron phosphate $\left(\mathrm{LiFePO}_{4} / \mathrm{LFP}\right)$ [12]. The anode is usually made of graphite or a metal oxide. The electrolyte can be liquid, polymer or solid.

The operating temperature has a great effect on the discharging and charging performances such as voltage window, discharge capacity and life, etc. At lower operating temperature $\left(<20^{\circ} \mathrm{C}\right)$ leads into significant reduction in power capability and driving range, and even freezing phenomenon with electrolyte, while operating at higher temperature range $\left(>45^{\circ} \mathrm{C}\right)$ results in battery degradation $[13,14$, 15, 16]. Therefore, during discharging and charging, precautions must be taken since, for example exceeding voltage, current or power limits may result in battery cell damage. The possibility of thermal runaways also occurs if care is not taken $[17,18,19]$. Moreover, lithium-ion polymer batteries must be carefully monitored and managed (electrically and thermally) to avoid safety (inflammability) and performance related issues [20, 21, 22]. Hence, the battery thermal management system (BTMS) is required in order to maintain the temperature of the cells in a battery pack at required levels. Usually, the typical operating range of temperature for lithium-ion batteries is $20^{\circ} \mathrm{C}$ and $45^{\circ} \mathrm{C}$, which gives the maximum power capability as well as the cycle life, and an extended range is between $-10^{\circ} \mathrm{C}$ and $+50^{\circ} \mathrm{C}$ for the tolerable operation $[23,24,13]$.

Battery modeling is considered extremely important since it provides information on battery charging/discharging, transient behavior and health status of the battery (battery degradation) as a function of different stress factors (temperature, discharge rate, etc.). The battery models are also used for on-line self-learning performance and SOC estimation in BTMS [25, 26, 27]. There are various papers in the open literature available for battery thermal modeling, using different approaches such as artificial neural network [28, 29], finite element model (FEM) [30] or lumped parameter model (LPM) [31], linear parameter varying (LPV) model [32], or partial differential equation (PDE) model [33] and CFD models $[34,35,36,37,38,8]$. 
In this paper, the research conducted on the lithium-ion battery pack performance under different constant current discharge rates of $1 \mathrm{C}, 2 \mathrm{C}, 3 \mathrm{C}$, and $4 \mathrm{C}$ and $5^{\circ} \mathrm{C}, 15^{\circ} \mathrm{C}, 25^{\circ} \mathrm{C}$, and $35^{\circ} \mathrm{C} \mathrm{BCs}$ is presented. For the present study, we designed and developed an experimental facility which tests different batteries with different kind of chemistries. To the best of the authors' knowledge no similar studies have been reported in the literature. This study has the following objectives:

- Design and development of battery pack with three series connected lithium-ion batteries and four cold plates.

- Testing of pack under different C-rates and various boundary conditions.

- Experimental investigation of battery cells/pack in terms of surface temperature and voltage distributions.

- Development of the Thevenin based equivalent circuit model and validation with the test data.

\section{Experimental Study}

The experimental set-up used for the experimental work is shown in Figure 1. This set-up consists mainly of five components: A \& D cell/pack cycler, National Instrument (NI) temperature measurement device, battery pack, Computer 1, and Computer 2. A \& D cell/pack cycler (Bitrode) having a maximum capacity to charge/discharge at $20 \mathrm{~V}$ and $1200 \mathrm{~A}$, has been used to charge and discharge the battery pack. The cell/pack cycler has been controlled by Computer 2 through Visual CN software. Computer 1 provides the charge and discharge data for pack, while computer 2 is used for the thermal data collection. Computer-1 sets the current or voltage values on the load box and power supply, depending on the experiment. The current, measured internally of the load box and power supply, is transmitted back to Computer-1. Depending on the computer requests, the power supply or load box will provide power to or draw power from the battery pack, respectively. NI (National Instrument) 16 channel Field point is used in order to measure the surface temperature distributions, which transmits the thermal data to the test stand Computer 2. Heavy duty copper cables have been used to connect battery pack to the cycler.

The T-type thermocouples were installed on the principal surface of the battery to measure the surface temperatures at three discrete points. The thermocouple locations are shown in Figure 2 (a and b). All thermocouples were connected to NI temperature measurement device, which further connected to Computer 1. Out of three thermocouples, the first was placed near the cathode, the second was placed near the anode, and the third was placed at the mid surface of the cell. There were total eighteen thermocouples were used for this experimental set-up, out of eighteen, the six were used for first cell, the other six were used for the second cell, and the last six were used for the third cell and all cells are connected in series. Kapton-backed adhesive tape was used to adhere the thermocouples to the surface of 
the battery and thermocouples are T-type 30 gauge, special limits of error (SLE) thermocouple wire with uncertainty of $1{ }^{\circ} \mathrm{C}$ (according to manufacturer's specifications). The circuit model parameters for A123 AMP20 cells were found by hybrid pulse power characterization (HPPC) at $5^{\circ} \mathrm{C}, 10^{\circ} \mathrm{C}, 15^{\circ} \mathrm{C}, 20^{\circ} \mathrm{C}, 25^{\circ} \mathrm{C}$, $30^{\circ} \mathrm{C}, 35^{\circ} \mathrm{C}, 40^{\circ} \mathrm{C}, 45^{\circ} \mathrm{C}, 50^{\circ} \mathrm{C}, 55^{\circ} \mathrm{C}$, and $60^{\circ} \mathrm{C}$. A BioLogic VMP3B-100 multi-channel potentiostat was used for cell cycling and a CSZ Micro Climate chamber for temperature control. Circuit parameters were determined for SOC values from $10 \%$ to $90 \%$ at $10 \%$ intervals at each temperature.

In EV applications, the battery system consists of a number of single cells connected either in series or in parallel in order to achieve the power and capacity requirements. The pack as shown in Figure 1, consists of three cells electrically connected in series. As explained in previous paragraph, the pack was instrumented with T-type thermocouples, as well as pack current and individual cell voltage sensors. In this series, each battery cell was experimentally characterized, in order to predict the cell voltage and capacity during discharging and charging operations at an ambient temperature $\left(\sim 22^{\circ} \mathrm{C}\right)$. In all the experiments conducted, the cells were initially charged, then utilized until completely discharged. The output voltage of series connected cells is given by Equation 1 and the discharge current is given by Equation 2. It is very well known that the temperature distribution is not uniform in a battery pack. Therefore, the operating temperatures of the cells are different from each other.

$$
\begin{aligned}
& V_{\text {out }}=V_{\text {cell } 1}+V_{\text {cell } 2}+\cdots+V_{\text {cell } n} \\
& I_{\text {out }}=I_{\text {cell } 1}=I_{\text {cell } 2}=\cdots=I_{\text {cell } n}
\end{aligned}
$$

A $20 \mathrm{Ah}$ lithium-ion pouch cell was used for the test measurements and subsequent model validation. The main technical parameters of the battery are listed in Table 1 .

In the experimental measurements, three different discharge rates were selected: $1 \mathrm{C}, 2 \mathrm{C}, 3 \mathrm{C}$, and $4 \mathrm{C}$. The charge rate is $1 \mathrm{C}$. The experimental plan is shown in Table 2. The internal resistance is calculated based on the Ohm's law (covering the voltage drop (difference between open circuit voltage and the actual or measured terminal voltage) is divided by current values) as follows:

$$
r_{\text {int }}=\frac{\Delta V}{I}=\frac{V_{o c}-V_{a c t}}{I}
$$

\section{Analysis}

The Thevenin equivalent circuit model shown in Figure 3 was used for voltage estimation. The opencircuit voltage (OCV) was modeled by an ideal voltage source, with was correlated with the battery stateof-charge (SOC). The two resistors $\left(R_{1}\right.$ and $\left.R_{2}\right)$ and the capacitor $(\mathrm{C})$ were used to represent battery 
behaviour in response to current. These three parameters were found from the HPPC data using a genetic algorithm in MATLAB. This circuit model yields Equations 4-6, which were solved in the model to estimate the voltage of the battery.

$$
\begin{gathered}
V=O C V(S O C)-V_{1}-V_{2} \\
V_{1}=I R_{1} \\
\frac{d V_{2}}{d t}=-\frac{V_{2}}{R_{2} C}+\frac{I}{C}
\end{gathered}
$$

Figure 4 is an upper-level view of the MATLAB Simulink model used to estimate voltage, heat generation and temperature. Inputs to the voltage calculation subsystem were current and temperature. Current and the outputs of the voltage calculation subsystem were taken as inputs to the heat generation subsystem. Figure 5 shows the Simulink block diagram for voltage calculation. SOC was estimated

simply by coulomb integration. OCV and $\frac{d V_{O C}}{d T}$ lookup was based on SOC. A lookup table based on the work by Forgez et al. [45] was used in this subsystem. The parameter estimation subsystem took temperature and SOC as inputs to two-dimensional lookup tables for each circuit parameter. The voltage estimation subsystem then solved the system of circuit equations. Error! Reference source not found. shows the Simulink block diagram for heat generation. The inputs are used to solve the energy balance based on heat generation, cooling and ambient heat losses.

\section{Results and Discussion}

In this section, the experimental and simulated results for surface temperature and discharge voltage distributions are presented for a large size prismatic lithium-ion battery pack at different charge and discharge rates of $1 \mathrm{C}, 2 \mathrm{C}, 3 \mathrm{C}$, and $4 \mathrm{C}$ and different boundary conditions of $5^{\circ} \mathrm{C}, 15^{\circ} \mathrm{C}, 25^{\circ} \mathrm{C}$, and $35^{\circ} \mathrm{C}$ for water cooling and $\sim 22^{\circ} \mathrm{C}$ for air cooling methods.

\subsection{Average Surface Temperature Results}

Figure 6 shows the average surface temperature distributions obtained for stack or cell 1, 2, and 3 at different constant current C-rates of $1 \mathrm{C}, 2 \mathrm{C}, 3 \mathrm{C}$, and $4 \mathrm{C}$ and different boundary conditions of $5^{\circ} \mathrm{C}, 15^{\circ} \mathrm{C}$, $25^{\circ} \mathrm{C}$, and $35^{\circ} \mathrm{C}$ for water cooling and $\sim 22^{\circ} \mathrm{C}$ for air cooling method. Here, in this experimental work the cycle represents first $1 \mathrm{C}$ charge, then 1 hour rest, followed by $1 \mathrm{C}$ discharge, after that the same cycle is repeated but for discharging instead of $1 \mathrm{C}$ it is $2 \mathrm{C}, 3 \mathrm{C}$, and $4 \mathrm{C}$ discharge and total time for all charge/discharge cycle was 18 hours. Note that TC 1 is located near the positive electrode or cathode, TC 
2 is located near the negative electrode or anode, and TC 3 is located at the middle of the cell along the height of the cell as shown in Fig. 7. The highest value of the average surface temperature is obtained for $4 \mathrm{C}$ and $35^{\circ} \mathrm{C} \mathrm{BC}\left(36.36^{\circ} \mathrm{C}\right)$ and the lowest value is obtained for $1 \mathrm{C}$ and $5^{\circ} \mathrm{C} \mathrm{BC}\left(7.22^{\circ} \mathrm{C}\right)$. The trend observed is that the increased C-rates and increased boundary conditions result in increased in an average surface temperature for all cells 1, 2, and 3 (or stack). For the air cooling method, the values are higher at all discharge rates as compared to the water cooling method. The highest value of average surface temperature for the air cooling method obtained at $4 \mathrm{C}$ discharge rate is $41.38^{\circ} \mathrm{C}$. Table 3 summarized the average surface temperatures all C-rates and all BCs for both water cooling as well as air cooling methods.

\subsection{Peak Surface Temperature Results}

In Table 4, the peak surface temperature measured by the thermocouples for all discharge rates of 1C, 2C, $3 \mathrm{C}$, and $4 \mathrm{C}$ and different boundary conditions of $5^{\circ} \mathrm{C}, 15^{\circ} \mathrm{C}, 25^{\circ} \mathrm{C}$, and $35^{\circ} \mathrm{C}$ for the water cooling and $\sim 22^{\circ} \mathrm{C}$ for the air cooling methods are presented. It is observed that the highest peak surface temperatures were measured at TC 3 (near mid surface of the body). In general, for all tests the sensors nearest the middle of the battery surface measured greater values than the sensor located near electrodes. The trend observed is that increased discharge rates and increased boundary conditions (for both the water cooling and the air cooling) results in increased peak temperatures at the three locations measured. The highest value is obtained for $4 \mathrm{C}$ and $35^{\circ} \mathrm{C} \mathrm{BC}\left(38.82^{\circ} \mathrm{C}\right)$ and the lowest value is obtained for $1 \mathrm{C}$ and $5^{\circ} \mathrm{C} \mathrm{BC}$ $\left(8.17^{\circ} \mathrm{C}\right)$ for the water cooling method. Also, as compared to the water cooling method, the air cooling method gives higher values for all C-rates. The highest value for the air cooling method was at $4 \mathrm{C}$ discharge rate is $56.49^{\circ} \mathrm{C}$.

\subsection{Cell and Stack Voltage Results}

Figure 7 shows a stack voltage profile obtained during all discharge rates of $1 \mathrm{C}, 2 \mathrm{C}, 3 \mathrm{C}$, and 4C and different boundary conditions of $5^{\circ} \mathrm{C}, 15^{\circ} \mathrm{C}, 25^{\circ} \mathrm{C}$, and $35^{\circ} \mathrm{C}$ for the water cooling method. The voltage window for Cell 1, cell 2, and cell 3 are between $4.0 \mathrm{~V}$ and $2.0 \mathrm{~V}$ while for the stack, as they are connected in series, the voltage is between 11.0 and $6 \mathrm{~V}$. Here, the all three cells are charged with constant current $(\mathrm{CC})$ protocol until the voltage reaches $3.6 \mathrm{~V}$ and discharged with the constant current (CC) until the voltage drops to $2.0 \mathrm{~V}$. Here, the discharging and charging were done at constant current (CC). There is a great impact of boundary conditions $\left(5^{\circ} \mathrm{C}, 15^{\circ} \mathrm{C}, 25^{\circ} \mathrm{C}\right.$, and $\left.35^{\circ} \mathrm{C}\right)$ on the discharge capacity of the cells. It was observed that as the $\mathrm{BCs}$ increases the discharge capacity of all cells decreases.

\subsection{Model Validation Results}


Figure 8 shows a comparison between the experimental (red dotted lines and green solid line) and simulated (blue solid line) results for temperature distribution at $4 \mathrm{C}$ discharge rates versus the discharge time (s) for air cooling method. It shows a good agreement between the experimental and simulation data which is indicative of the accuracy of the present model. However, at the higher C-rates of 4C, some discrepancies are observed. The model predicts the lower value than the experimental values at higher discharge rates of $4 \mathrm{C}$, while for the other discharge rate of $1 \mathrm{C}, 2 \mathrm{C}$, and $3 \mathrm{C}$ the model predicts the higher values than the actual values. The reason behind this is that more accurate input data is required to get the exact output. In general, the trend observed is that as the C-rate increases the surface temperature also increases. Similarly, Figure 9 shows a comparison between experimental (blue solid line) and simulated (red dotted line) for the discharge voltage during 4C discharge rate for an air cooling method. Similarly, Figure 10 shows a comparison between experimental (blue solid line) and simulated (red dotted line) for the discharge voltage during $1 \mathrm{C}, 2 \mathrm{C}$, and $3 \mathrm{C}$ discharge rate for an air cooling method. It was observed that for the air cooling method, the discharge capacity is closer to the manufacturer's provided capacity (20Ah) for all C-rates.

\section{Conclusions}

This paper has presented a comparative study of the temperature distribution on a prismatic lithium-ion battery pack consisting of three cells in series connection using both experimental and simulation techniques. In the experimental study, the temperature distribution on lithium-ion battery cells at $1 \mathrm{C}, 2 \mathrm{C}$, $3 \mathrm{C}$, and $4 \mathrm{C}$ constant current discharge rates and various $\mathrm{BCs}$ of $5^{\circ} \mathrm{C}, 15^{\circ} \mathrm{C}, 25^{\circ} \mathrm{C}$, and $35^{\circ} \mathrm{C}$ boundary conditions (BCs) for a water cooling method and $\sim 22^{\circ} \mathrm{C}$ for an air cooling method were studied. The average and peak surface temperature values are also obtained from the experimental data. Computationally, a high-fidelity curve fitting model was also developed, and the simulated data are then validated with the experimental data for the average temperature of all three cells and voltage profiles. The developed model successfully captured the charge/discharge behaviour over a wide range of $\mathrm{C}$ rates. Some concluding remarks are stated as follows: (i) the temperature distributions of all three cells increase as the C-rates increase. (ii) For the water cooling method, the highest value of average surface temperature is obtained for $4 \mathrm{C}$ and $35^{\circ} \mathrm{C} \mathrm{BC}\left(38.82^{\circ} \mathrm{C}\right)$ and the lowest value is obtained for $1 \mathrm{C}$ and $5^{\circ} \mathrm{C}$ $\mathrm{BC}\left(8.17^{\circ} \mathrm{C}\right)$. (iii) For the air cooling method, the highest value of average surface temperature obtained at $4 \mathrm{C}$ discharge rate is $41.38^{\circ} \mathrm{C}$. (iv) The water cooling method is more effective than an air cooling method. These kinds of testing and results provide an insight into the design and optimization of battery systems. Future work will focus on a more rigorous thermal testing under controlled $\mathrm{BCs}$ of $10^{\circ} \mathrm{C}, 20^{\circ} \mathrm{C}, 30^{\circ} \mathrm{C}$ and $40^{\circ} \mathrm{C}$. 


\section{Nomenclature}

$\begin{array}{ll}I & =\text { current }[\mathrm{A}] \\ R & =\text { resistance }[\Omega] \\ C & =\text { capacitance } \\ T & =\text { temperature }\left[{ }^{\circ} \mathrm{C} \text { or } \mathrm{K}\right] \\ t & =\text { time }[\mathrm{s}] \\ V & =\text { cell voltage or cell potential }[\mathrm{V}]\end{array}$

\section{Subscripts}

$\begin{array}{ll}\text { act } & =\text { actual } \\ \text { int } & =\text { internal } \\ \text { oc } & =\text { open-circuit } \\ \text { out } & =\text { output }\end{array}$

\section{Acronyms}

$\mathrm{BC}$

BMS

BTMS

$\mathrm{C}$

$\mathrm{CC}$

$\mathrm{CV}$

EV

HEV

HPPC

GUI

$\mathrm{I} / \mathrm{O}$

$\mathrm{LiCoO}_{2}$

$\mathrm{LiMn}_{2} \mathrm{O}_{4}$

$\mathrm{LiNiMnCoO}_{2}$

$\mathrm{LiFePO}_{4}$

LCO

LFP

LPM

LPV

NI

NMC

OCV

PHEV

PDE

TC

SOC
Boundary condition

Battery management system

Battery thermal management system

Capacity

Constant-current

Constant-voltage

Electric vehicle

Hybrid electric vehicle

Hybrid pulse power characterization

Graphical user interface

Input/output

Lithium cobalt oxide

Lithium manganese oxide

Lithium manganese cobalt oxide

Lithium iron phosphate

Lithium cobalt oxide

Lithium phosphate

Lumped parameter model

Linear parameter varying

National Instrument

Lithium manganese cobalt oxide

Open circuit voltage

Plug-In hybrid electric vehicle

Partial differential equation

Thermocouple

State of charge

\section{References}


[1] A. Barai, K. Uddin, W. D. Widanalage, A. McGordon and P. Jennings, "The effect of average cycling current on total energy of lithium-ion batteries for electric vehicles," Journal of Power Sources, vol. 303, pp. 81-85, 2016.

[2] B. Scrosati and J. Garche, "Lithium batteries: Status, prospects and future," Journal of Power Sources, vol. 195, no. 9, pp. 2419-2430, 2010.

[3] Z. Ling, F. Wang, X. Fang, X. Gao and Z. Zhang, "A hybrid thermal management system for lithium ion batteries combining phase change materials with forced-air cooling," Applied Energy, no. 148, pp. 403-409, 2015.

[4] H. Ge, J. Huang, J. Zhang and Z. Li, "Temperature-Adaptive Alternating Current Preheating of Lithium-Ion Batteries with Lithium Deposition Prevention," Journal of The Electrochemical Society, vol. 163, no. 2, pp. A290-A299, 2016.

[5] A. Ritchie and W. Howard, "Recent developments and likely advances in lithium-ion batteries," Journal of Power Sources, vol. 162, pp. 809-812, 2006.

[6] Y. Ye, L. H. Saw, Y. Shi and A. A. Tay, "Numerical analyses on optimizing a heat pipe thermal management system for lithium-ion batteries during fast charging," Applied Thermal Engineering, vol. 86, pp. 281-291, 2015.

[7] M. Malik, I. Dincer and M. Rosen, "Review on use of phase change materials in battery thermal management for electric and hybrid electric vehicles," International Journal of Energy Research, 2016.

[8] K. Yeow, M. Thelliez, H. Teng and E. Tan, "Thermal Analysis of a Li-ion Battery System with Indirect Liquid Cooling Using Finite Element Analysis Approach," SAE International Journal, vol. 1, no. 1, pp. 65-78, 2012.

[9] A. Dinger, R. Martin, X. Mosquet, M. Rabl, D. Rizoulis and G. Sticher, "Batteries for Electric Cars,Challenges, Opportunities, and the Outlook to 2020," The Boston Consulting Group, 2010.

[10] L. Y. Shao-Horn, C. Delmas, C. E. Nelson and M. A. O'Keefe, "Atomic resolution of lithium ions in LiCoO2," Nature Materials, vol. 2, pp. 464-467, 2003.

[11] C. Julien, "Local Structure of lithiated manganese oxides," Solid State Ionics, vol. 177, pp. 11-19, 2006.

[12] J. T. Bloking, S. Y. Chung and Y. M. Chiang, "Electrically conductive phospho-olivines as lithium storage electrodes," Nature Materials, vol. 1, pp. 123-128, 2002.

[13] N. Yang, X. Zhang, B. Shang and G. Li, "Unbalanced discharging and aging due to temperature differences among the cells in a lithium-ion battery pack with parallel combination," Journal of Power Sources, vol. 306, pp. 733-741, 2016.

[14] J. Wang, P. Liu, J. Hicks-Garner, E. Sherman, S. Soukiazian, M. Verbrugge, H. Tataria, J. Musser and P. Finamore, "Cycle-life model for graphite-LiFePO4 cells," Journal of Power Sources, vol. 196, no. 8, pp. 3942-3948, 2011. 
[15] N. Yang, X. Zhang and G. Li, "State of charge estimation for pulse discharge of a LiFePO4 battery by a revised Ah counting," Electrochimica Acta, vol. 151, pp. 63-71, 2015.

[16] N. Yang, X. Zhang, G. Li and D. Hua, "Assessment of the forced air-cooling performance for cylindrical lithium-ion battery packs: A comparative analysis between aligned and staggered cell arrangements," Applied Thermal Engineering, vol. 80, pp. 55-65, 2015.

[17] M. J. Isaacson, R. P. Hollandsworth, P. J. Giampaoli, F. A. Linkowsky, A. Salim and V. L. Teofilo, "Advanced Lithium-ion battery charger," Battery conference on Applications and Advances, pp. 193-198, 2000.

[18] J. McDowall, P. Biensan and M. Broussely, "Industrial Lithium-ion battery safety-What are the tradeoffs?," in Telecommunications Energy Conference, 2007.

[19] S. Panchal, I. Dincer, M. Agelin-Chaab, R. Fraser and M. Fowler, "Experimental temperature distributions in a prismatic lithium-ion battery at varying conditions," International Communications in Heat and Mass Transfer, vol. 71, pp. 35-43, 2016.

[20] Y. Xing, Q. Miao, K.-L. Tsui and M. Pecht, "Prognostics and health monitoring for lithium-ion battery," in IEEE International Conference on, 2011.

[21] X. Feng, M. Fang, X. He, M. Ouyang, L. Lu, H. Wang and M. Zhang, "Thermal runaway features of large format prismatic lithium ion battery using extended volume accelerating rate calorimetry," Journal of Power Sources, pp. 255 : 294-301, 2014.

[22] L. Lu, X. Han, J. Hua, M. Ouyang and J. Li, "A review on the key issues for lithium-ion battery management in electric vehicles," Journal of Power Sources, pp. 226:272-288, 2013.

[23] F. He and L. Ma, "Thermal Management in Hybrid Power Systems Using Cylindrical and Prismatic Battery Cells," Heat Transfer Engineering, vol. 37, no. 6, pp. 581-590, 2016.

[24] I. Bayraktar, "Computational Simulation Methods for Vehicle Thermal Management," Applied Thermal Engineering, vol. 36, pp. 325-329, 2012.

[25] O. Erdinc, B. Vural and M. Uzunoglu, "A dynamic Lithium-ion Battery Model Considering the Effects of Temperature and Capacity Fading, Clean Electrical Power," in International Conference, IEEE, pp. 383-386., 2009.

[26] L. Lam, P. Bauer and E. Kelder, "A Practical Circuit-Based Model for Li-ion Battery Cells in Electric Vehicle Applications," in In Telecommunications Energy Conference (INTELEC), IEEE 33rd International, pp. 1-9., 2011.

[27] A. Ostadi, M. Kazerani and S. K. Chen, "Optimal Sizing of the Energy Storage System (ESS) in a Battery-Electric Vehicle," Transportation Electrication Conference and Expo (ITEC), IEEE, pp. 1-6, 2013.

[28] S. Panchal, I. Dincer, M. Agelin-Chaab, R. Fraser and M. Fowler, "Experimental and theoretical investigation of temperature distributions in a prismatic lithium-ion battery," International Journal of Thermal Sciences, no. 99, pp. 204-212, 2016. 
[29] S. Panchal, I. Dincer, M. Agelin-Chaab, R. Fraser and M. Fowler, "Thermal modeling and validation of temperature distributions in a prismatic lithium-ion battery at different discharge rates and varying boundary conditions," Applied Thermal Engineering, 2016.

[30] A. Pruteanu, B. V. Florean, G. Maria Moraru and R. C. Ciobanu, "Development of a thermal simulation and testing model for a superior lithium-ion-polymer battery," in Optimization of Electrical and Electronic Equipment (OPTIM), IEEE, pages 947-952, 2012.

[31] C. Alaoui, "Solid-State Thermal Management for Lithium-Ion EV Batteries," Vehicular Technology, IEEE Transactions on, vol. 62, no. 1, pp. 98-107, 2013.

[32] X. Hu, S. Asgari, S. Lin, S. Stanton and W. Lian, "A linear parameter-varying model for HEV/EV battery thermal modeling," in Energy Conversion Congress and Exposition (ECCE), IEEE, pages 1643-1649, 2012.

[33] A. Smyshlyaev, M. Krstic, N. Chaturvedi, J. Ahmed and A. Kojic, "PDE model for thermal dynamics of a large," in American Control Conference (ACC), IEEE, pages 959-964, 2011.

[34] A. Samba, N. Omar, H. Gualous, Y. Firouz, P. V. d. Bossche, J. V. Mierlo and T. I. Boubekeur, "Development of an Advanced Two-Dimensional Thermal Model for Large size Lithium-ion Pouch Cells," Electrochimica Acta, vol. 117, pp. 246-254, 2014.

[35] G. Li and S. Li, "Physics-Based CFD Simulation of Lithium-ion Battery under the FUDS Driving Cycle," ECS Transactions, vol. 64, no. 33, pp. 1-14, 2015.

[36] P. Vyroubal, T. Kazda, J. Maxa and J. Vondrák, "Analysis of Temperature Field in Lithium Ion Battery by discharging," ECS Transactions, vol. 70, no. 1, pp. 269-273, 2015.

[37] C. H. Wang, T. Lin, J. T. Huang and Z. H. Rao, "Temperature response of a high power lithium-ion battery subjected to high current discharge," Materials Research Innovations, vol. 19, pp. 156-160, 2015.

[38] L. W. Jin, P. S. Lee, X. X. Kong, Y. Fan and S. K. Chou, "Ultra-thin minichannel LCP for EV battery thermal management," Applied Energy, vol. 113, pp. 1786-1794, 2014.

[39] M. Jourdan, H. Mounir and A. El Mariani, "Compilation of factors affecting durability of Proton Exchange Membrane Fuel Cells (PEMFC)," in Renewable and Sustainable Energy Conference (IRSEC), International, 2014.

[40] C. R. Pals and J. Newman, "Thermal modeling of the lithium/polymer battery," Journal of the Electrochemical Society, vol. 142, no. 10, pp. 3274-3281, 1995.

[41] Y. Chen and J. W. Evans, "Three-dimensional thermal modeling of lithium-polymer batteries under galvanostatic discharge and dynamic power profile," Journal of the Electrochemical Society, vol. 141, no. 11, pp. 2947-2952, 1994.

[42] G. Wierschem, B. McKinney and E. Nrotek, "Thermal management of lead-acid batteries for electric vehicles," in Research and developement testing, Detroit, 1993. 
[43] A. A. Pesaran, A. Vlahinos and S. D. Burch, "Thermal performance of EV and HEV battery modules and packs," National Renewable Energy Laboratory, Golden, Colorado, 1997.

[44] K. Smith and C.-Y. Wang, "Power and thermal characterization of a lithium-ion battery pack for hybrid-electric vehicles," Journal of Power Sources, vol. 160, no. 1, pp. 662-673, 2006.

[45] H. Fathabadi, "A novel design including cooling media for Lithium-ion batteries pack used in hybrid and electric vehicles," Journal of Power Sources, vol. 245, pp. 495-500, 2014. 


\section{List of Table}

Table 1: $\mathrm{LiFePO}_{4}-20 \mathrm{Ah}$ lithium-ion pouch cell specifications

Table 2: Experimental plan e

Table 3: Summary of average surface temperature at all discharge rates and different BCs

Table 4: Summary of peak surface temperature at all discharge rates and different BCs

\section{List of Figure}

Figure 1: Experimental set-up

Figure 2: Thermocouples locations; (a) drawing with dimensions, (b) actual cell with thermocouple

Figure 3: Thevenin equivalent circuit model

Figure 4: Main Simulink block diagram

Figure 5: Simulink block diagram for voltage

Figure 6: Experimental surface temperature profiles during different discharge rates and various boundary conditions

Figure 7: Experimental voltage profiles during different discharge rates and various boundary conditions

Figure 8: Comparison between the experimental (solid lines) and numerical (dots) results during 4C-rates without cooling

Figure 9: Comparison between the experimental (solid lines) and numerical (dots) results during 4C-rates without cooling

Figure 10: Comparison between the experimental (solid lines) and numerical (dots) results during different discharge rates without cooling 


\section{Tables}

Table $1: \mathrm{LiFePO}_{4}$ - 20Ah lithium-ion pouch cell specifications

\begin{tabular}{|l|l|}
\hline \multicolumn{1}{|c|}{ Specifications } & \multicolumn{1}{c|}{ Value } \\
\hline Cathode Material & $\mathrm{LiFePO}_{4}$ \\
\hline Anode Material & Graphite \\
\hline Electrolyte & Carbonate based \\
\hline Nominal Capacity & $20.0 \mathrm{Ah}$ \\
\hline Nominal Voltage & $3.3 \mathrm{~V}$ \\
\hline Dimensions & $7.25 \mathrm{~mm} \times 160 \mathrm{~mm} \times 227 \mathrm{~mm}$ \\
\hline
\end{tabular}

Table 2 : Test conditions

\begin{tabular}{|c|c|c|}
\hline $\begin{array}{c}\text { Cooling } \\
\text { Type }\end{array}$ & $\begin{array}{c}\text { Ambient/Coolant/Bath } \\
\text { Temperature }\left[{ }^{\circ} \mathbf{C}\right]\end{array}$ & $\begin{array}{c}\text { Discharge } \\
\text { Rate }\end{array}$ \\
\hline \multirow{2}{*}{ Air cooling } & $\sim 22$ & $1 \mathrm{C}, 2 \mathrm{C}, 3 \mathrm{C}, 4 \mathrm{C}$ \\
\hline \multirow{3}{*}{ Water cooling } & 5 & $1 \mathrm{C}, 2 \mathrm{C}, 3 \mathrm{C}, 4 \mathrm{C}$ \\
\cline { 2 - 3 } & 15 & $1 \mathrm{C}, 2 \mathrm{C}, 3 \mathrm{C}, 4 \mathrm{C}$ \\
\cline { 2 - 3 } & 25 & $1 \mathrm{C}, 2 \mathrm{C}, 3 \mathrm{C}, 4 \mathrm{C}$ \\
\cline { 2 - 3 } & 35 & $1 \mathrm{C}, 2 \mathrm{C}, 3 \mathrm{C}, 4 \mathrm{C}$ \\
\hline
\end{tabular}

Table 3 : Summary of average surface temperature at all discharge rates and different BCs

\begin{tabular}{|c|c|c|c|c|c|}
\hline \multirow{2}{*}{$\begin{array}{c}\text { Cooling } \\
\text { Type }\end{array}$} & $\begin{array}{c}\text { Boundary } \\
\text { Condition } \\
{\left[{ }^{\circ} \mathbf{C}\right]}\end{array}$ & \multicolumn{4}{|c|}{ Average surface temperature [ } \\
\cline { 2 - 6 } & 5 & $\mathbf{1 C}$ & $\mathbf{2 C}$ & $\mathbf{3 C}$ & $\mathbf{4 C}$ \\
\hline \multirow{3}{*}{$\begin{array}{c}\text { Water } \\
\text { cooling }\end{array}$} & 15 & 7.22 & 8.49 & 10.43 & 11.58 \\
\cline { 2 - 6 } & 25 & 25.30 & 26.15 & 27.44 & 28.25 \\
\cline { 2 - 6 } & 35 & 35.17 & 35.34 & 36.35 & 36.36 \\
\hline Air & $\sim 22$ & 27.86 & 34.18 & 36.86 & 41.38 \\
\hline
\end{tabular}

Table 4 : Summary of peak surface temperature at all discharge rates and different BCs

\begin{tabular}{|c|c|c|c|c|c|}
\hline \multirow{2}{*}{$\begin{array}{c}\text { Cooling } \\
\text { Type }\end{array}$} & \multirow{2}{*}{$\begin{array}{c}\text { Boundary } \\
\text { Condition }\left[{ }^{\circ} \mathbf{C}\right]\end{array}$} & \multicolumn{4}{|c|}{ Maximum surface temperature [ $\left.{ }^{\circ} \mathbf{C}\right]$} \\
\cline { 3 - 6 } & 5 & $\mathbf{1 C}$ & $\mathbf{2 C}$ & $\mathbf{3 C}$ & $\mathbf{4 C}$ \\
\hline \multirow{3}{*}{$\begin{array}{c}\text { Water } \\
\text { cooling }\end{array}$} & 15 & 8.17 & 9.78 & 12.44 & 13.89 \\
\cline { 2 - 6 } & 25 & 25.58 & 26.82 & 28.90 & 30.66 \\
\cline { 2 - 6 } & 35 & 35.34 & 36.24 & 38.01 & 38.82 \\
\hline Air & $\sim 22$ & 32.99 & 42.72 & 48.61 & 56.49 \\
\hline
\end{tabular}




\section{Figures}

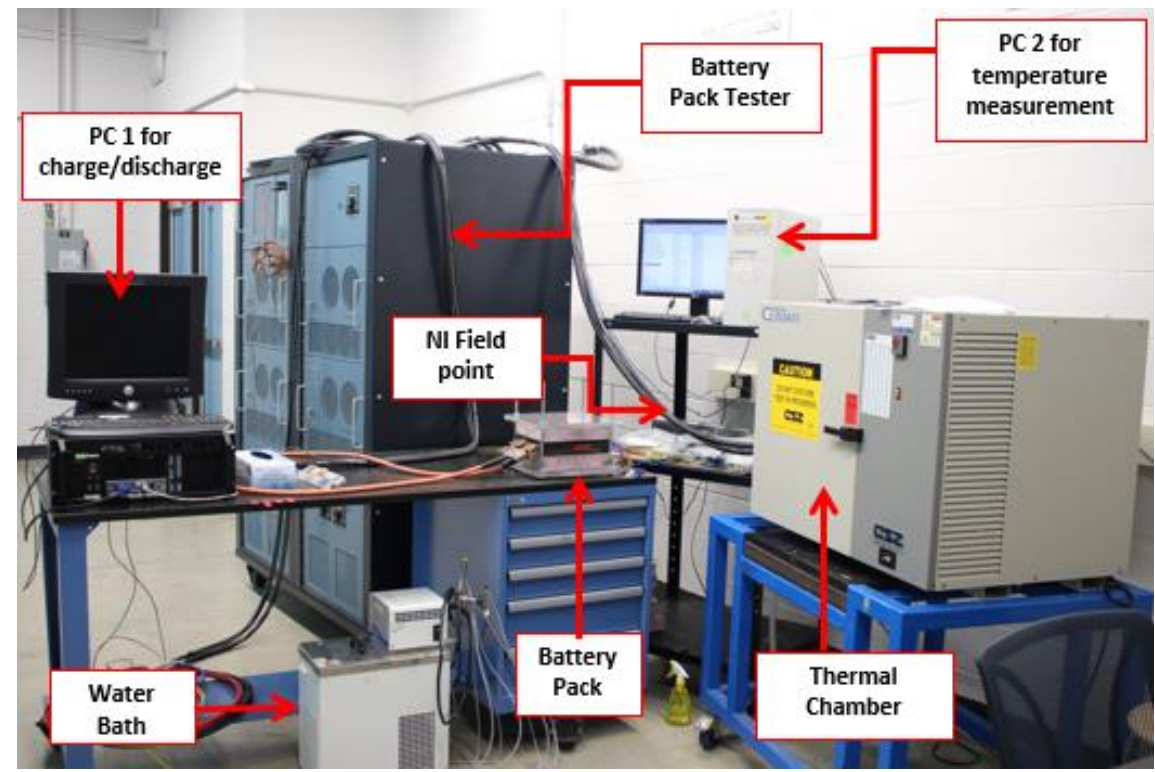

Figure 1 : Experimental set-up

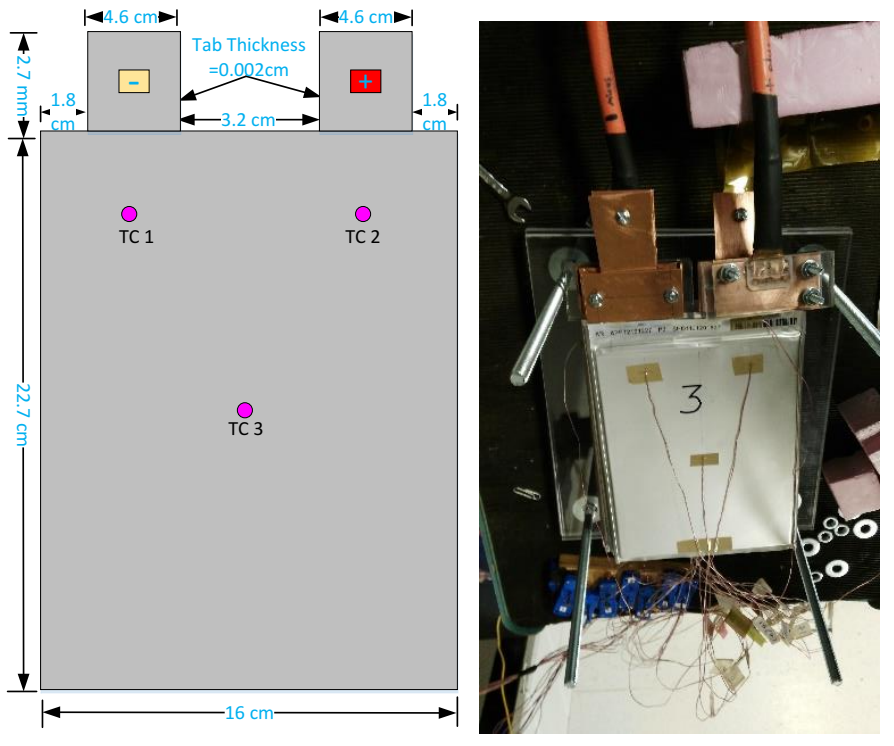

(a)

(b)

Figure 2 : Thermocouples locations; (a) drawing with dimensions, (b) actual cell with thermocouple. 


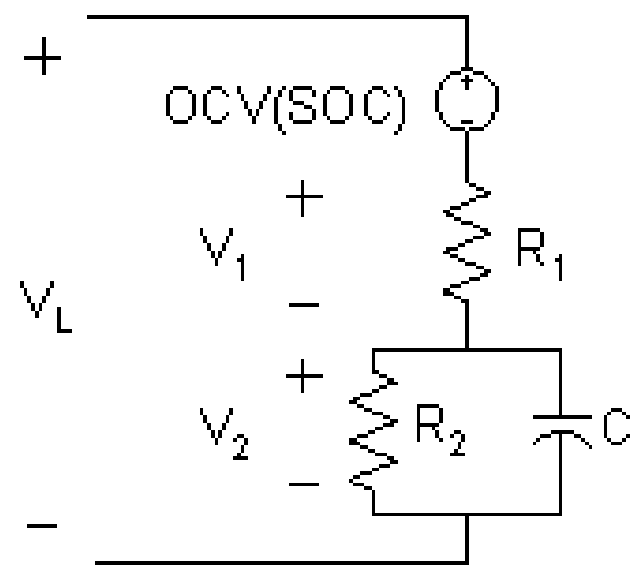

Figure 3 : Thevenin equivalent circuit model

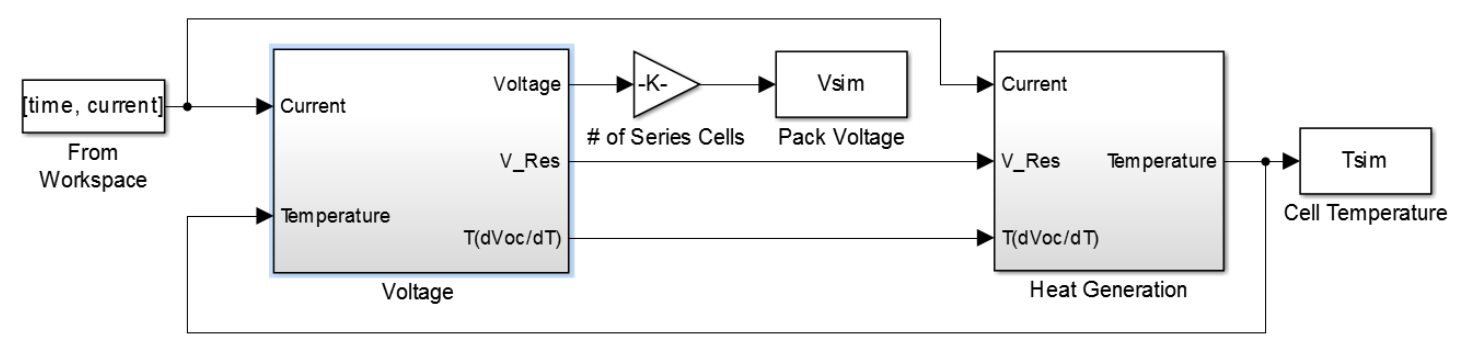

Figure 4 : Main Simulink block diagram

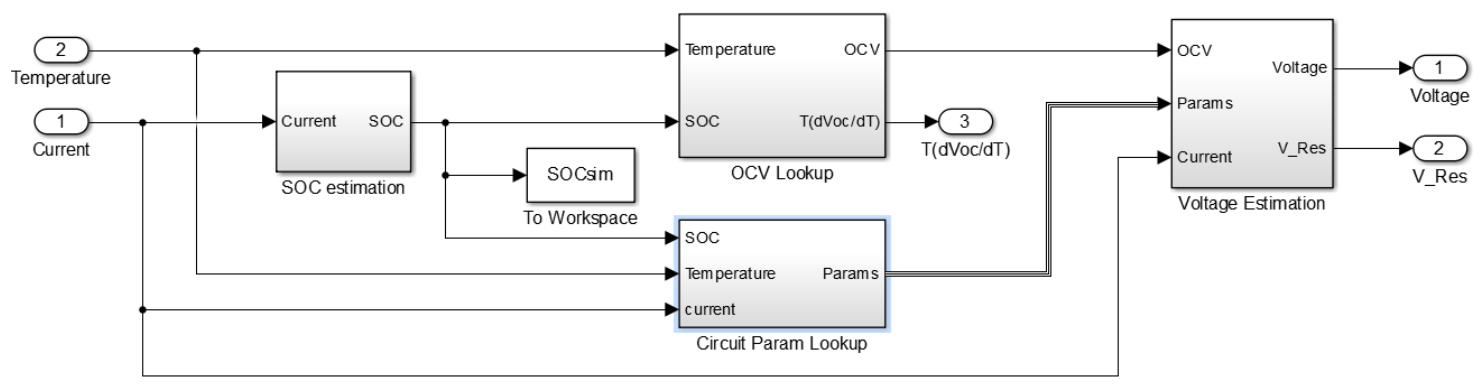

Figure 5 : Simulink block diagram for voltage 


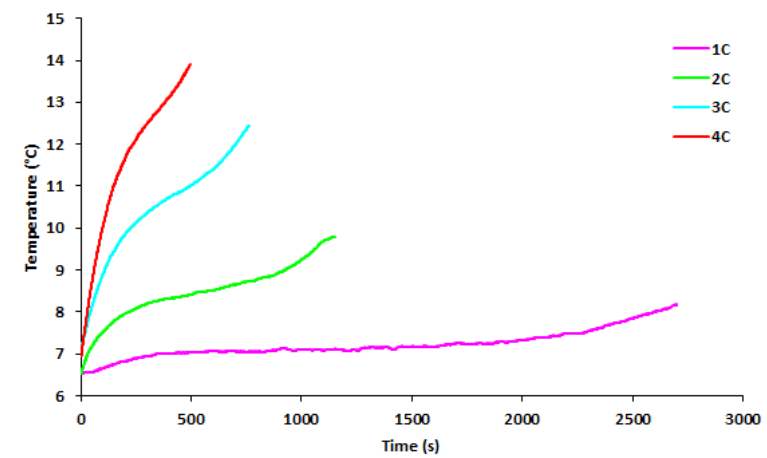

(a) Temperature at $1 \mathrm{C}, 2 \mathrm{C}, 3 \mathrm{C}, 4 \mathrm{C}$ and $5^{\circ} \mathrm{C} \mathrm{BC}$

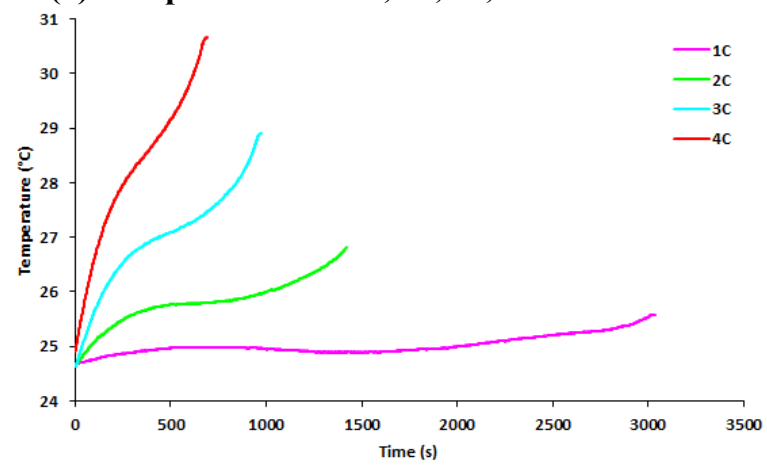

(c) Temperature at $1 \mathrm{C}, 2 \mathrm{C}, 3 \mathrm{C}, 4 \mathrm{C}$ and $25^{\circ} \mathrm{C}$ BC

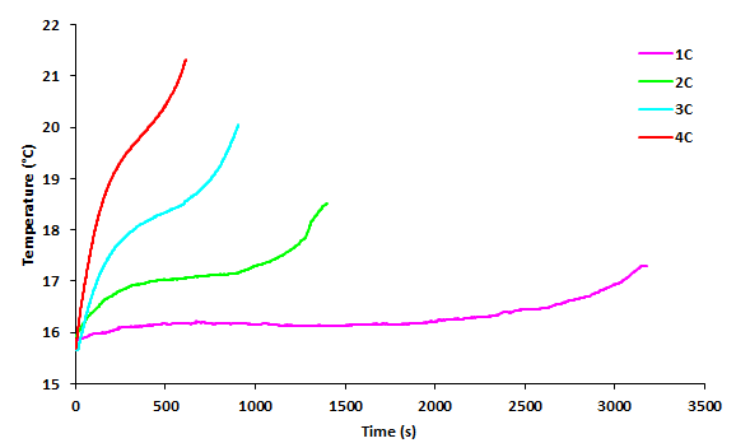

(b) Temperature at $1 \mathrm{C}, 2 \mathrm{C}, 3 \mathrm{C}, 4 \mathrm{C}$ and $15^{\circ} \mathrm{C}$ BC

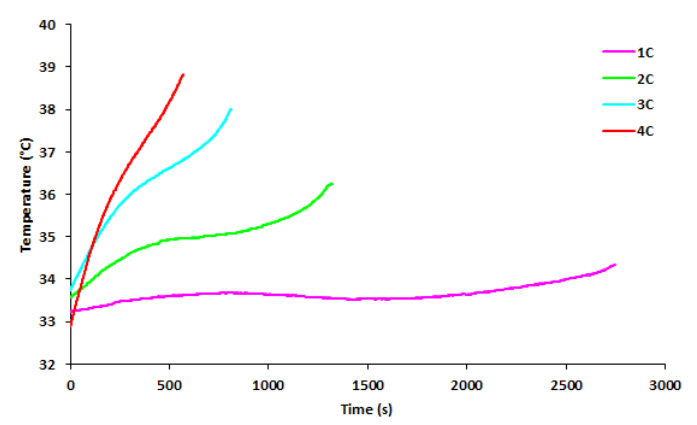

(d) Temperature at $1 \mathrm{C}, 2 \mathrm{C}, 3 \mathrm{C}, 4 \mathrm{C}$ and $35^{\circ} \mathrm{C} \mathrm{BC}$

Figure 6 : Experimental surface temperature profiles during different discharge rates and various boundary conditions

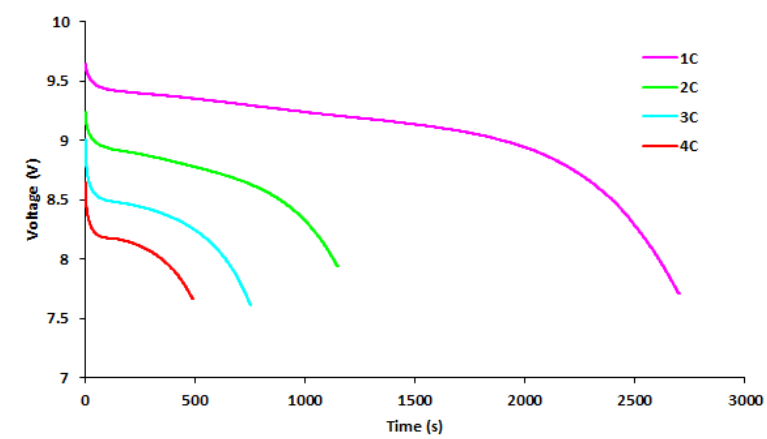

(a) Voltage at $1 \mathrm{C}, 2 \mathrm{C}, 3 \mathrm{C}, 4 \mathrm{C}$ and $5^{\circ} \mathrm{C} \mathrm{BC}$

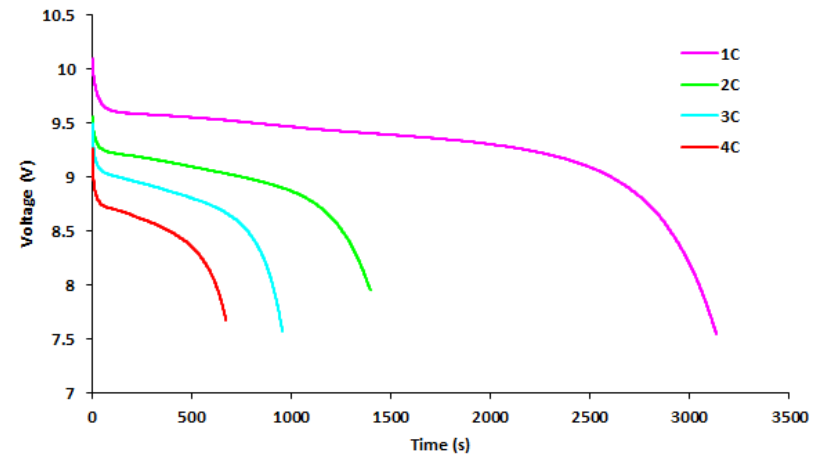

(c) Voltage at $1 \mathrm{C}, 2 \mathrm{C}, 3 \mathrm{C}, 4 \mathrm{C}$ and $25^{\circ} \mathrm{C}$ BC

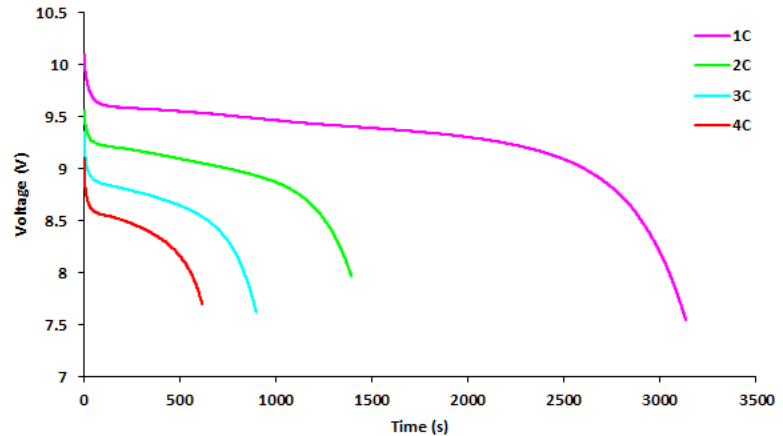

(b) Voltage at $1 \mathrm{C}, 2 \mathrm{C}, 3 \mathrm{C}, 4 \mathrm{C}$ and $15{ }^{\circ} \mathrm{C} \mathrm{BC}$

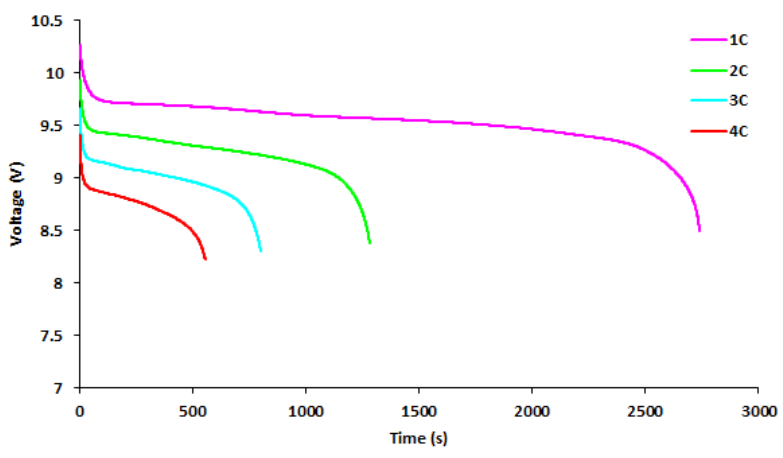

(d) Voltage at $1 \mathrm{C}, 2 \mathrm{C}, 3 \mathrm{C}, 4 \mathrm{C}$ and $35^{\circ} \mathrm{C}$ BC

Figure 7 : Experimental voltage profiles during different discharge rates and various boundary conditions 


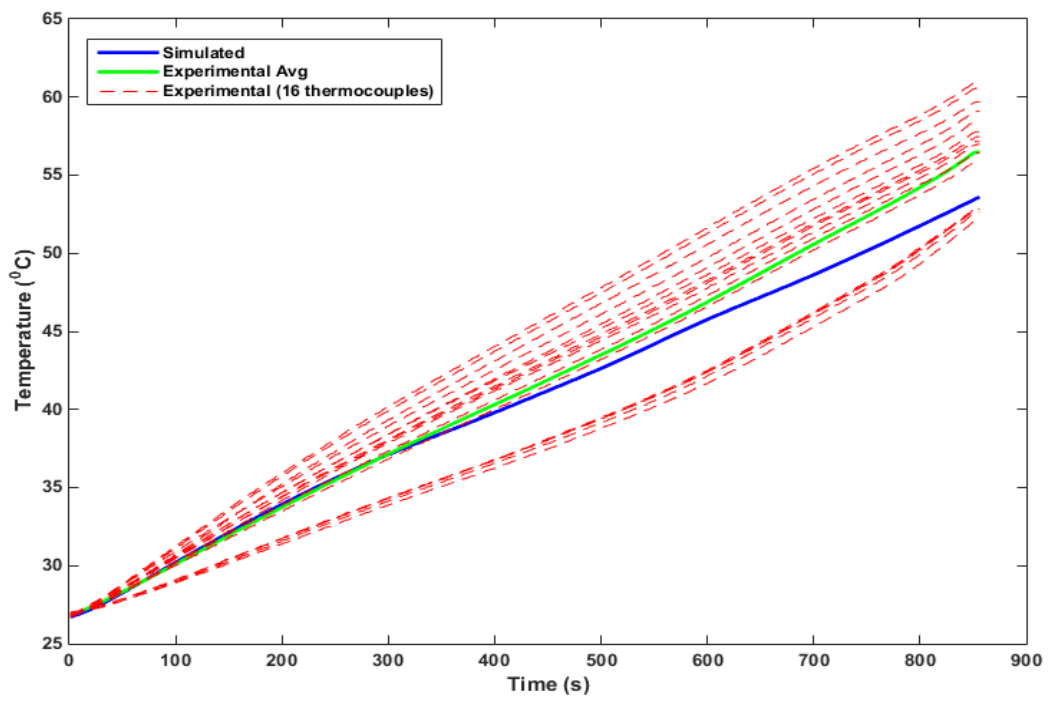

Figure 8 : Comparison between the experimental (solid lines) and numerical (dotted lines) results for temperatures during $4 \mathrm{C}$-rates without cooling

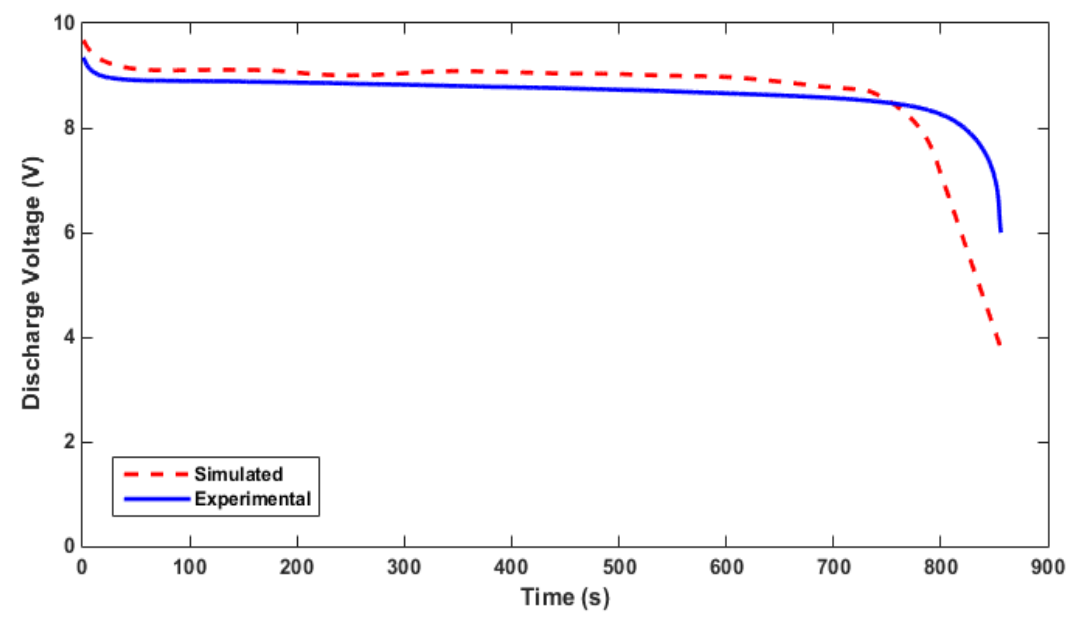

Figure 9 : Comparison between the experimental (solid lines) and numerical (dotted lines) results for discharge voltage during $4 \mathrm{C}$-rates without cooling 


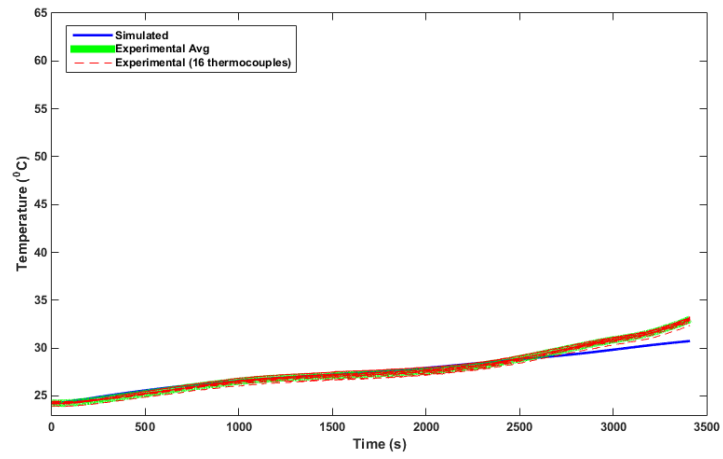

(a) 1C_Temperature_Nocooling BC

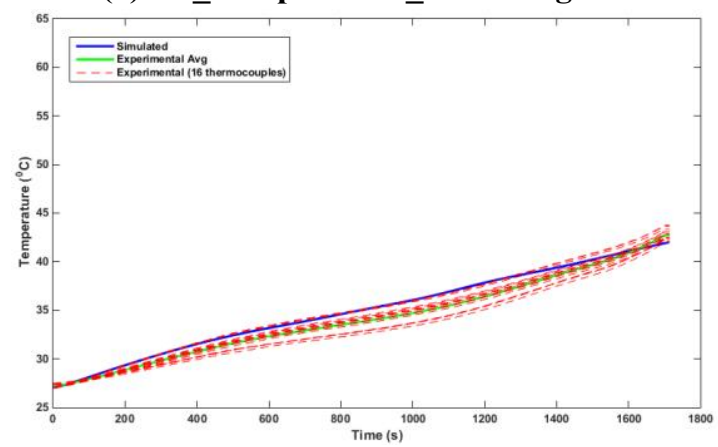

(b) 2C_Temperature_Nocooling BC

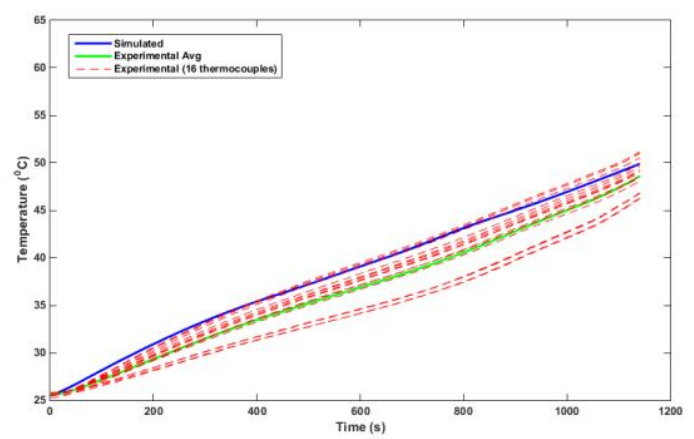

(c) 3C_Temperature BC

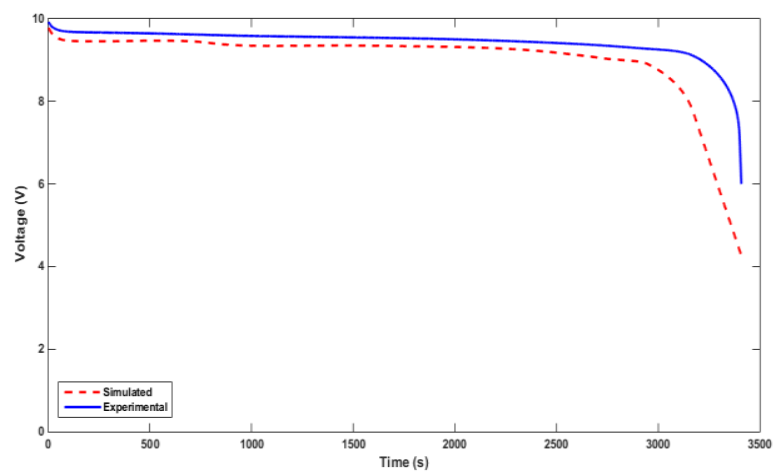

(a) 1C_Voltage_Nocooling BC

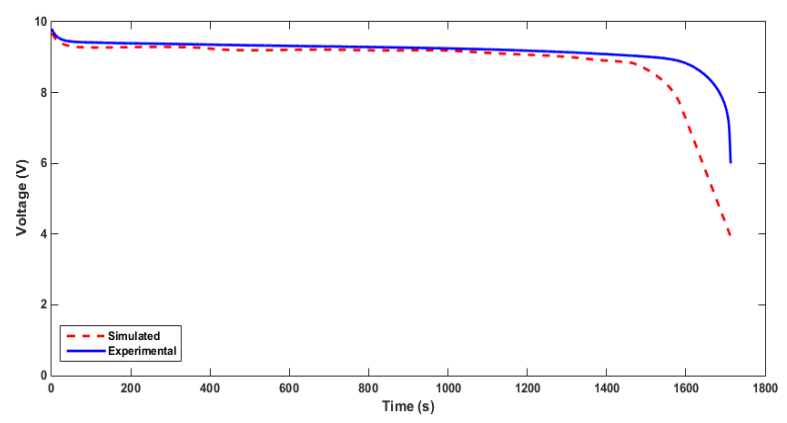

(b) 2C_Voltage_Nocooling BC

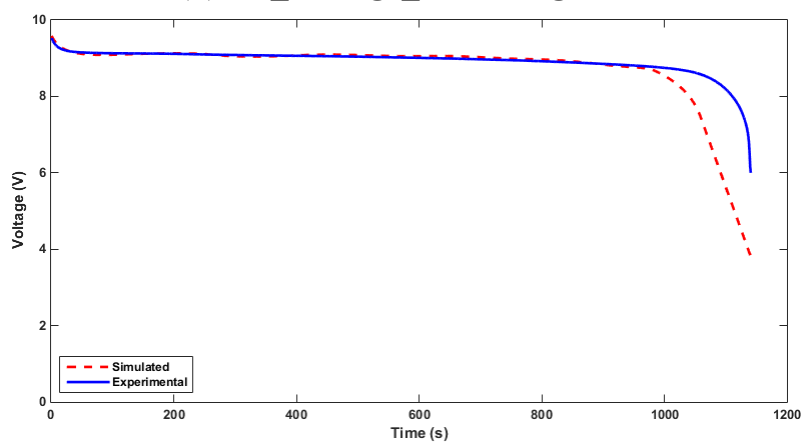

(c) 3C_Voltage_Nocooling BC

Figure 10 : Comparison between the experimental (solid lines) and numerical (dotted lines) results during different discharge rates without cooling 